\title{
Midwives' knowledge and utilization of non-pneumatic anti shock garment in reducing complication of postpartum haemorrhage in selected health care facilities in Bayelsa state Nigeria
}

\author{
Olayinka A. Onasoga ${ }^{1 *}$, Emon Duke ${ }^{2}$, Imabin U. Danide ${ }^{1}$, Izibeloko Omi Jack-Ide ${ }^{1}$
}

\author{
${ }^{1}$ Faculty of Nursing, Niger Delta University, Wilberforce Island, Bayelsa State, Nigeria \\ ${ }^{2}$ Department of Nursing Science, College of Medical Sciences, University of Calabar, Calabar, Nigeria
}

Received: 13 April 2015

Revised: 19 April 2015

Accepted: 09 May 2015

\section{*Correspondence:}

Olayinka A. Onasoga,

E-mail: yinka_onasoga@yahoo.com

Copyright: (C) the author(s), publisher and licensee Medip Academy. This is an open-access article distributed under the terms of the Creative Commons Attribution Non-Commercial License, which permits unrestricted non-commercial use, distribution, and reproduction in any medium, provided the original work is properly cited.

\begin{abstract}
Background: Non-pneumatic anti-shock garment (NASG) is a first-aid lower-body pressure device that reverses hypovolaemic shock and decreases obstetric hemorrhage thereby decreasing maternal morbidity and mortality due to post-partum haemorrhage (PPH).This study assessed the knowledge and utilization of non-pneumatic anti shock garment in the management of postpartum hemorrhage among midwives in selected health care facilities in Bayelsa state.

Methods: This is a descriptive cross-sectional study in which a sample size of 112 nurses were selected using purposive sampling technique. The instrument for data collection was questionnaire and data collected were analyzed using descriptive and inferential statistics.

Results: The study revealed that majority of the respondents regardless of their educational level had good knowledge of the description, mechanism of action, and uses of NASG. It was also revealed that majority of the respondents do not use NASG in their centers and its application in management of post-partum hemorrhage was not part of the protocols in these centers, which was a clear indication of underutilization of the NASG in the primary health care centers. There was no significant association found between years of working experience of respondents and their utilization of NASG with $\left(\mathrm{X}^{2}=8.577, \mathrm{df}=2, \mathrm{P}=0.114\right)$ as well as between the level of knowledge of midwives and their utilization of the NASG with $\left(\mathrm{X}^{2}=0.387, \mathrm{df}=1, \mathrm{P}=0.534\right)$.

Conclusions: It was recommended that non-pneumonic antishock garment should be made available by government and its utilization should be included in all health care centers policy as a management protocol for post-partum hemorrhage.
\end{abstract}

Keywords: Knowledge, Midwives, Utilization, Non pneumatic Antishock garment, Post-partum hemorrhage

\section{INTRODUCTION}

The world leaders in 2000 decided that improving maternal health should be one of the 8 millennium development goals for the international community because of the problem of increase maternal deaths, of which postpartum hemorrhage (PPH) is one of the causes. ${ }^{1}$ Postpartum haemorrhage (PPH) is one of the leading causes of maternal mortality and severe maternal morbidityand is defined as blood loss greater than $500 \mathrm{ml}$ during a vaginal delivery or greater than $100 \mathrm{ml}$ with a cesarean delivery. ${ }^{2,3}$

PPH accounts for about a quarter of all maternal deaths and an estimate of 342900 women die from complication of pregnancy and childbirth each year, out of which $99 \%$ occur in developing countries with PPH responsible for about 25 percent of all the maternal deaths. World Health 
Organization (WHO) reported that 127000 of these deaths annually are owing to postpartum hemorrhage worldwide. ${ }^{3,4}$

Meyer et al. stated that $30 \%$ of maternal deaths in Africa are due to postpartum hemorrhage. ${ }^{5}$ This is to say that postpartum hemorrhage is a major threat to maternal health and a myth to achievement of millennium development goal 5 of improving maternal health. ${ }^{6}$ Nevertheless, these are unnecessary deaths that can be prevented and one way of preventing these deaths is by the use of the Non-pneumatic anti shock garment (NASG) which is low technology first aid device that can be placed around the lower body of a woman who has gone in to shock from obstetric bleeding. This garment decreases blood loss, recovers women from shock and keeps them alive while awaiting treatment

According Miller et al., the NASG is a low-technology pressure device that decreases blood loss, restores vital signs, and has the potential to improve adverse outcomes by helping women survive delays in receiving adequate emergency obstetric care. ${ }^{7}$ The NASG significantly reduced blood loss, time to recovery from shock, and, for those with postpartum hemorrhage due to uterine atony who received oxytocin, the NASG had a significant effect on blood loss independent of oxytocin.

Oladosu et al. stated that the NASG is a first aid care that significantly reduced mortality even among women who were in severe shock. ${ }^{8}$ When delays in the management of PPH occur, first aid is needed to resuscitate and stabilize women with PPH until definitive treatment is obtained. The NASG made from neoprene and velcro each of its six segments is sequentially wrapped tightly around a hemorrhaging woman's legs, pelvis and abdomen. The abdominal segment applies extra compression with a small foam ball. The circumferential counter pressure applied by the NASG Decreases the total vascular space in the lower portion of the body while simultaneously increasing the volume of the blood in the central circulation. Thus, oxygenated blood is shunted to vital organs. ${ }^{9}$ Using the NASG does not prevent further examination of the woman as it allows for vaginal procedures with the NASG in place and abdominal examination are also performed by opening the abdominal section during surgery.

The use of the garment for obstetrical hemorrhage in lowresource settings began in 2002 when Brees and Hensleigh introduced the garment in to a hospital in Pakistan and reported on a case series of its use. ${ }^{10}$ The NASG's effectiveness has been proven, according to Miller et al., (2007), women treated with the NASG will improve much better than women who are not. Furthermore, women in the NASG phase experienced better outcomes. ${ }^{8}$

According to Onasoga et al., Midwives are the first point of contact for most women during pregnancy and labour and all women are at risk of PPH, therefore midwives' knowledge and utilization of the NASG which is a quick and adequate way of providing emergency obstetric care during PPH especially in limited resource area where there is accessibility problems during transport or referral as well as delays in receiving care. ${ }^{11}$ Hence, the overall objective of this study was to assess midwives' knowledge and utilization of the NASG in the management of postpartum hemorrhage.

\section{METHODS}

This is a descriptive cross-sectional study carried out in two government owned health care facilities in Bayelsa State. These health facilities were chosen because they have high patronage of clients for maternity. The target population for this study consists of all registered midwives working in these health centres at the time of this study. The sample size of 112 respondents were used. The instrument for data collection was a self-developed questionnaire which consists of three sections: section $\mathrm{A}$ consists of demographic data of respondents, section $\mathrm{B}$ consists of questions focusing on knowledge of midwives on NASG while section $\mathrm{C}$ focuses on utilization of NASG. The questionnaire contained 21 items made of open and close ended questions. Permission to carry out the study was obtained from the health centres and the researchers distributed the questionnaires personally. The respondents' consent was sought, confidentiality and anonymity was also maintained. Both descriptive and inferential statistics were used to analyze the data collected. Descriptive statistics in form of frequencies and percentages, and Pearson's chi square was used to established relationships between certain variables and utilization of the NASG by nurse-midwives under study with level of significance set at $\mathrm{P}>0.05$.

\section{RESULTS}

Table 1 shows that of the 112 respondents, 50 (44.6\%) of the respondents were between 25-30 years, 40 (35.7\%) were between 36-45 years while 22 (19.6\%) were between 46-56 years old. Majority 85 (75.9\%) of the respondents were females while $27(24.1 \%)$ were males.

$34(30 \%)$ of the respondents were CNOs, $30(26.8 \%)$ were NO1, 29 (25.9) were NO2 while the remaining 19 (17\%) were PNOs. Most 69 (61.6\%) of respondents had 11 years and above working experience, while 22 (19.6\%) had 4-6 years working experience, and 21 $(18.8 \%)$ had $1-5$ years working experience.

Majority of the respondents 91 (81.2\%) were diploma (RNM) holders, 13 (11.6\%) were B.Sc. holders, and only $8(7.1 \%)$ were M.Sc. holders. 
Table 1: Showing demographic variables of respondents $(n=112)$.

\begin{tabular}{|llll|} 
Variable & Frequency & $\begin{array}{l}\text { Percentage } \\
(\%)\end{array}$ \\
\hline \multirow{4}{*}{ Age } & $25-35$ & 50 & 44.6 \\
& $36-45$ & 40 & 35.7 \\
& $46-56$ & 22 & 19.6 \\
\hline \multirow{2}{*}{ Sex } & Male & 27 & 24.1 \\
& Female & 85 & 75.9 \\
\hline \multirow{5}{*}{ Rank } & NO 1 & 30 & 26.8 \\
& NO 2 & 29 & 25.9 \\
& PNO & 19 & 17.0 \\
Working & CNO & 34 & 30.4 \\
\hline \multirow{5}{*}{ Qualification } & 1-5 years & 21 & 18.8 \\
& 6-10 years & 22 & 19.6 \\
& 11years & & \\
& and above & 69 & 61.6 \\
\hline & Diploma & 91 & 81.2 \\
& B.Sc. & 13 & \\
& M.Sc. & 8 & 7.1 \\
\hline
\end{tabular}

Table 2: Showing knowledge of respondent on NASG $(n=112)$.

\begin{tabular}{|c|c|c|c|}
\hline Variable & & Frequency & $\%$ \\
\hline $\begin{array}{l}\text { Have you heard of } \\
\text { the non-pneumatic } \\
\text { antishock garment }\end{array}$ & $\begin{array}{l}\text { Yes } \\
\text { No }\end{array}$ & $\begin{array}{l}112 \\
0\end{array}$ & $\begin{array}{l}100 \\
0\end{array}$ \\
\hline $\begin{array}{l}\text { Have you ever seen } \\
\text { the NASG }\end{array}$ & $\begin{array}{l}\text { Yes } \\
\text { No }\end{array}$ & $\begin{array}{l}105 \\
7\end{array}$ & $\begin{array}{l}93.7 \\
6.3\end{array}$ \\
\hline $\begin{array}{l}\text { Where did you first } \\
\text { hear it }\end{array}$ & $\begin{array}{l}\text { Hospital } \\
\text { School } \\
\text { Seminar }\end{array}$ & $\begin{array}{l}43 \\
54 \\
15\end{array}$ & $\begin{array}{l}38.4 \\
48.2 \\
13.4\end{array}$ \\
\hline $\begin{array}{l}\text { What is the NASG } \\
\text { like? }\end{array}$ & $\begin{array}{l}\text { Bottom } \\
\text { half of a } \\
\text { suit } \\
\text { A gown } \\
\text { A trouser }\end{array}$ & $\begin{array}{l}8 \\
81\end{array}$ & $\begin{array}{l}7.1 \\
72.3\end{array}$ \\
\hline $\begin{array}{l}\text { Do you know what } \\
\text { the NASG is used for }\end{array}$ & $\begin{array}{l}\text { Yes } \\
\text { No }\end{array}$ & $\begin{array}{l}106 \\
6\end{array}$ & $\begin{array}{l}94.6 \\
5.4\end{array}$ \\
\hline If yes, state its uses & $\begin{array}{l}\text { Correct } \\
\text { incorrect }\end{array}$ & $\begin{array}{l}93 \\
13\end{array}$ & $\begin{array}{l}87.7 \\
12.3\end{array}$ \\
\hline What is it made of & $\begin{array}{l}\text { Rubber } \\
\text { neoprene }\end{array}$ & $\begin{array}{l}16 \\
96\end{array}$ & $\begin{array}{l}14.3 \\
85.7\end{array}$ \\
\hline $\begin{array}{l}\text { How many parts } \\
\text { have the NASG }\end{array}$ & $\begin{array}{l}\text { Four } \\
\text { Six } \\
\text { eight }\end{array}$ & $\begin{array}{l}14 \\
39 \\
59\end{array}$ & $\begin{array}{l}12.5 \\
34.8 \\
52.7\end{array}$ \\
\hline $\begin{array}{l}\text { Can the NASG be } \\
\text { used in managing } \\
\text { PPH }\end{array}$ & $\begin{array}{l}\text { Yes } \\
\text { No }\end{array}$ & $\begin{array}{l}112 \\
0\end{array}$ & $\begin{array}{l}100 \\
0\end{array}$ \\
\hline $\begin{array}{l}\text { The NASG work by } \\
\text { forcing blood from } \\
\text { the lower part of the } \\
\text { body to vital organs }\end{array}$ & $\begin{array}{l}\text { Yes } \\
\text { No }\end{array}$ & $\begin{array}{l}91 \\
21\end{array}$ & $\begin{array}{l}81.2 \\
18.8\end{array}$ \\
\hline $\begin{array}{l}\text { The NASG can also } \\
\text { be used when a } \\
\text { woman is already in } \\
\text { shock }\end{array}$ & $\begin{array}{l}\text { Yes } \\
\text { No }\end{array}$ & $\begin{array}{l}107 \\
5\end{array}$ & $\begin{array}{c}95.5 \\
4.5\end{array}$ \\
\hline
\end{tabular}

Table 2 shows that $112(100 \%)$ of the respondents have heard of the NASG and majority $105(93.7 \%)$ have seen it, $54(48.2 \%)$ first heard about it in the school, 43 $(38.4 \%)$ in hospital while the remaining $15(13.4 \%)$ heard about it in seminar. $93(87.7 \%)$ were able to state correctly two of its uses while $13(12.3 \%)$ could not state correctly its use. $81(72.3 \%)$ said the NASG is like a trouser, $23(20.5 \%)$ said it is like bottom half of a suit and $8(7.1 \%)$ say it is like a gown. Only $96(85.7 \%)$ said that the NASG is made of neoprene while $16(14.3 \%)$ said rubber. $59(52.7 \%)$ said the NASG have eight parts, 39 $(34.8 \%)$ said six and $14(12.5 \%)$ said four parts. All the respondents $112(100 \%)$ said that the NASG can be used to manage PPH and $91(81.2 \%)$ opined that the NASG work by forcing blood from the lower part of the body to vital organs but $21(18.8 \%)$ said otherwise. 107 (95.5\%) agree that the NASG can also be used when the woman is already in shock while 5 (4.5\%) disagreed.

Table 3: Showing respondents utilization of the NASG $(n=112)$.

\begin{tabular}{|c|c|c|c|}
\hline \multirow{2}{*}{$\begin{array}{l}\text { Variables } \\
\text { Do you know } \\
\text { how to use the } \\
\text { NASG }\end{array}$} & & Frequency & $\%$ \\
\hline & $\begin{array}{l}\text { Yes } \\
\text { No }\end{array}$ & $\begin{array}{l}70 \\
42\end{array}$ & $\begin{array}{l}62.5 \\
37.5\end{array}$ \\
\hline $\begin{array}{l}\text { Have you ever } \\
\text { used NASG in } \\
\text { the management } \\
\text { of PPH }\end{array}$ & $\begin{array}{l}\text { Yes } \\
\text { No }\end{array}$ & $\begin{array}{l}52 \\
60\end{array}$ & $\begin{array}{l}46.4 \\
53.6\end{array}$ \\
\hline $\begin{array}{l}\text { NASG is part of } \\
\text { your health care } \\
\text { protocol for PPH } \\
\text { before referral. }\end{array}$ & $\begin{array}{l}\text { Yes } \\
\text { No } \\
\text { I don't know }\end{array}$ & $\begin{array}{l}13 \\
38 \\
61\end{array}$ & $\begin{array}{l}11.6 \\
33.9 \\
54.5\end{array}$ \\
\hline $\begin{array}{l}\text { If yes, was it } \\
\text { effective }\end{array}$ & $\begin{array}{l}\text { Yes } \\
\text { Never use }\end{array}$ & $\begin{array}{l}52 \\
60 \\
\end{array}$ & $\begin{array}{l}46.4 \\
53.6 \\
\end{array}$ \\
\hline $\begin{array}{l}\text { Do you use } \\
\text { NASG every } \\
\text { time there is PPH }\end{array}$ & $\begin{array}{l}\text { No } \\
\text { Never use }\end{array}$ & $\begin{array}{l}52 \\
60\end{array}$ & $\begin{array}{l}46.4 \\
53.6\end{array}$ \\
\hline $\begin{array}{l}\text { If no, when do } \\
\text { you use it }\end{array}$ & $\begin{array}{l}\text { Severe PPH } \\
\text { Shock } \\
\text { When other } \\
\text { method fail } \\
\text { Never use }\end{array}$ & $\begin{array}{l}14 \\
18 \\
20 \\
60\end{array}$ & $\begin{array}{l}12.5 \\
16.1 \\
20.0 \\
53.6\end{array}$ \\
\hline $\begin{array}{l}\text { Do you use it, } \\
\text { when the need } \\
\text { arise in your } \\
\text { health center }\end{array}$ & $\begin{array}{l}\text { Yes } \\
\text { No }\end{array}$ & $\begin{array}{l}13 \\
99\end{array}$ & $\begin{array}{l}11.6 \\
88.4\end{array}$ \\
\hline If no why & $\begin{array}{l}\text { It is difficult } \\
\text { to assemble } \\
\text { It is not } \\
\text { available } \\
\text { I do not know } \\
\text { much about it }\end{array}$ & $\begin{array}{l}76 \\
35\end{array}$ & $\begin{array}{l}67.9 \\
31.2\end{array}$ \\
\hline $\begin{array}{l}\text { If you know how } \\
\text { to use it will you } \\
\text { use it }\end{array}$ & Yes & 112 & 100.0 \\
\hline $\begin{array}{l}\text { If it is available } \\
\text { will you use it }\end{array}$ & Yes & 112 & 100.0 \\
\hline
\end{tabular}


Table 3 shows that $70(62.5 \%)$ claimed to know how to use the NASG but only $52(46.4 \%)$ of the respondents have actually used it before while $60(53.6 \%)$ have not. Majority 61 (54.5\%) of the respondents doesn't know if NASG is part of their health care protocol for PPH before referral while $38(33.9 \%)$ said no and only $13(11.6 \%)$ said yes. All the $52(46.4 \%)$ respondents that have actually used the NASG opined that it is very effective and that it is not used every time there is $\mathrm{PPH}, 28$ $(25.0 \%)$ said that it is used When other methods failed, $18(16.1 \%)$ said that when shock ensued while 14 (12.5\%). Majority $99(88 \%)$ of the respondents does not use the NASG in their centers due to non-availability $(67.9 \%)$ and lack of skill $(31.2 \%)$ majorly. All of the respondent will use it if it is available and if they know how to use it.

Table 4: Relationship between years of working experience of respondents and their utilization of the NASG of respondents.

\begin{tabular}{|c|c|c|c|c|c|}
\hline \multirow[b]{2}{*}{ Variable } & \multicolumn{2}{|c|}{ Level of knowledge } & \multirow{2}{*}{$\begin{array}{l}\text { Pearson } \\
\text { Chi-square } \\
x^{2}(\mathbf{P} \text { value })\end{array}$} & \multirow[b]{2}{*}{ DF } & \multirow[b]{2}{*}{ Remark } \\
\hline & $\begin{array}{l}\text { Low } \\
\text { knowledge }\end{array}$ & $\begin{array}{l}\text { High } \\
\text { knowledge }\end{array}$ & & & \\
\hline $\begin{array}{l}\text { Working experience } \\
1-5 \text { years } \\
6-10 \text { years } \\
11 \text { years and above }\end{array}$ & $\begin{array}{l}5 \\
3 \\
31\end{array}$ & $\begin{array}{l}16 \\
19 \\
38\end{array}$ & $\begin{array}{l}8.577 \\
(0.114)\end{array}$ & 2 & $\begin{array}{l}\text { No } \\
\text { significant } \\
\text { association }\end{array}$ \\
\hline $\begin{array}{l}\text { Level of utilization } \\
\text { Low utilization } \\
\text { High utilization }\end{array}$ & $\begin{array}{l}25 \\
14\end{array}$ & $\begin{array}{l}51 \\
22\end{array}$ & $\begin{array}{l}3.387 \\
(0.534)\end{array}$ & 1 & $\begin{array}{l}\text { No } \\
\text { significant } \\
\text { association }\end{array}$ \\
\hline
\end{tabular}

Table 4 shows that there was no significant association found between years of working experience of respondents and their utilization of NASG with $\mathrm{P}$ value $=$ $0.114>0.05$, as well as between level of knowledge of respondents and their utilization of the NASG with $\mathrm{P}$ value $=0.534>0.05$.

\section{DISCUSSION}

Majority of respondents were females between 25-30 years, with more than 10years working experience. Most of the respondents were registered nurse-midwives and are Chief Nursing Officers (CNOs).

The study revealed that all the respondents have heard of the NASG and their initial source of information was the school. Most of the respondents have good knowledge about the description, mechanism of action, and uses of NASG. This implies that majority of the respondents were knowledgeable about NASG in the management of obstetric haemorrhage. The NASG is a simple neoprene and Velcro device that looks like the bottom half of a wetsuit cut into segments. It can be used to treat shock, resuscitate, stabilize and prevent further bleeding in woman with obstetric hemorrhage as documented by Miller et al. ${ }^{7}$

The finding from the study showed that more than half of the respondents have not used the NASG and the few that have used it, agreed that it is highly effective and less time consuming. This confirms the statement of Miller et al., ${ }^{7}$ that women treated with the NASG will get better much quickly than women not treated with it.
Furthermore, the study revealed that majority of the respondents do not use the NASG in their centers, even among those who have heard and seen the NASG, some do not know how to use it. It was also observed that the application of NASG was not part of the protocols for the management of post-partum hemorrhage in these centers. This is a clear indication of underutilization of the NASG among respondents despite the efficacy of non-pneumatic antishock garment in reducing maternal morbidity and mortality caused by obstetric haemorrhage-related complication. This was in line with the findings of Olowokere et al., ${ }^{12}$ where none of the facilities made use of this simple devise in the management and control of PPH. Furthermore, John and Catherine ${ }^{13}$ affirmed lack of adequate training and underutilization of the anti-shock garment in most developing countries of the globe. However, all the respondents stated that they will use it if it is available and if they know how to use it. This demonstrated the need for training programme on NASG in the management of PPH through seminars and workshops as well as need to supply NASG in various health care centers.

The study showed that there was no significant association between years of working experience of respondents and their utilization of NASG, as well as between level of knowledge of respondents and their utilization of the NASG with $P$ value $>0.05$. This shows that year of working experience and knowledge of NASG does not influence utilization of the NASG.

Based on the findings the following recommendations were made: 
i. Provision of adequate non-pneumonic antishock garment in all health care facilities in the state by government since availability is one major factor to utilization

ii. All health care facilities should include in their policy the use of non-pneumonic antishock garment as a management protocol for post-partum hemorrhage.

iii. Periodic training of nurse-midwives on the use of the non-pneumonic antishock garment in management of obstetric haemorrhage.

\section{Nursing implication}

Maternal mortality due to PPH remains a serious public health issues in developing countries like Nigeria. Adequate knowledge, availability and utilization of NASG is indispensable for all midwives since they are the first point of call in the health care centre and the Non-pneumatic anti-shock garment (NASG) is a lowtechnology device that offers a possible solution to counteract the effect of the delay in gaining access or providing obstetric care in a timely fashion, thus reducing maternal morbidity and mortality due to PPH.

Funding: No funding sources

Conflict of interest: None declared

Ethical approval: Approved

\section{REFERENCES}

1. WHO, UNICEF, UNFPA. Maternal mortality in 2000. In: WHO, eds. Estimates developed by WHO, UNICEF and UNFPA. Geneva: WHO; 2004.

2. Knight $\mathrm{M}$, Callaghan WM, Berg C, Alexander S, Bouver-Colle MH, Ford JB, et al. Trends in postpartum hemorrhage in high source countries: a review and recommendation from the International PPH Collaborative Group. BMC Pregnancy Childbirth. 2009;9:55.

3. Hogan, Margaret C, Foreman, Kyle J, Naghavi M, Ahn SY, et al. Maternal mortality for 181 countries, 1980-2008: a systematic analysis of progress towards Millennium Development Goal 5. Lancet. 2010;375(9726):1609-23.

4. Tsu VD, Shane B. New and underutilized technologies to reduce maternal mortality: call to action from a Bellagio workshop. Int $\mathrm{J}$ Gynaecol Obstet. 2004;85(Suppl 1):S83-93.
5. Ojengbede OA, Morhason-Bello IO, Galadanci H, Meyer C, Nsima D, Camlin C, et al. Assessing the role of the non-pneumatic anti-shock garment in reducing mortality from postpartum hemorrhage in Nigeria. Gynecol Obstet Invest. 2011;71(1):66-72.

6. Turan J, Ojengbede O, Fathalla M, Mourad-Youssif M, Morhason-Bello IO, Nsima D, et al. Posture effects of the non-pneumatic anti shock garment on delay, in accessing care of post-partum and post abortion hemorrhage in Egypt and Nigeria. J Womens Health (Larchmt). 2011;20(1):91-8.

7. Miller S, Ojengbede A, Turan JM. Anti-shock garments for obstetric hemorrhage. Curr Women's Health Rev. 2007;3(1):3-11.

8. Ojengbede OA, Morhason-Bello IO, Galadanci $\mathrm{H}$, Meyer C, Nsima D, Camlin C, et al. Assessing the role of the non-pneumatic anti-shock garment in reducing mortality from postpartum hemorrhage in Nigeria. Gynecol Obstet Invest. 2011;71(1):66-72.

9. Miller S, Hensleigh P. Non-pneumatic anti-shock garment for obstetric hemorrhage. In: B-Lynch C, Keith L, LaLonde A eds. An international Federation of Obstetrics and Gynecology (FIGO) Book. Postpartum Hemorrhage: New Thoughts, New Approaches. London, UK: Sapiens Publications; 2009: Chapter 14.

10. Hensleigh PA. Anti-shock garment provides resuscitation and haemostasis for obstetric hemorrhage. BJOG. 2002 Dec;109(12):1377-84.

11. Onasoga Olayinka A, Awhanaa Akpomeyoma T, Amiegheme Felicia E. Assessment of knowledge of strategies used in the prevention and management of postpartum hemorrhage by midwives in Bayelsa Nigeria. Arch Appl Sci Res. 2012;4(1):447-53.

12. Olowokere AE, Adekeye OA, Ogunfowokan A, Olagunju OE, Irinoye OO. The prevalence, management and outcome of primary postpartum haemorrhage in selected health care facilities in Nigeria. Int J Nurs Midwif. 2013;5(3):28-34.

13. John D, Catherine T. Assessment: the impact of the anti-shock garment on maternal mortality McArthur Foundation, 2013. Available at: http://www.macfound.org/media/files/AntiShockGar ment-Summary.pdf.

Cite this article as: Onasoga OA, Duke E, Danide IU, Jack-Ide IO. Midwives' knowledge and utilization of non-pneumatic anti shock garment in reducing complication of postpartum haemorrhage in selected health care facilities in Bayelsa state Nigeria. Int $\mathbf{J}$ Reprod Contracept Obstet Gynecol 2015;4:977-81. 